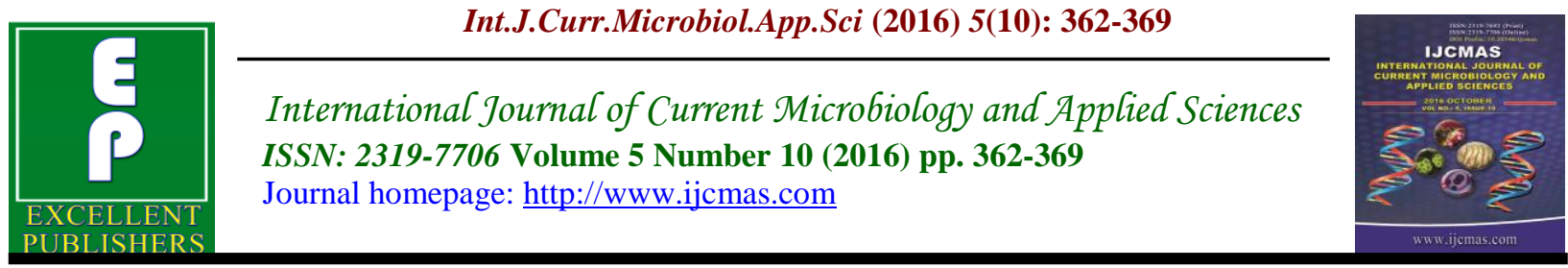

Original Research Article

http://dx.doi.org/10.20546/ijcmas.2016.510.041

\title{
Changes in Biomolecules of Groundnut Leaves infected with Rust (Puccinia arachidis Speg)
}

\author{
Y.M. Rojasara*, Rutika Shah, J.J. Dhuve and I.U. Dhruj \\ Anand Agricultural University, Anand, India \\ *Corresponding author
}

\section{A B S T R A C T}

Keywords

Groundnut, rust, fungicides, micronutrient content, TSS, protein, phenol, Amino acids.

\section{Article Info}

Accepted: 14 September 2016 Available Online: 10 October 2016
Groundnut (Arachis hypogaea L.) is an important oilseed crop contributing large share of vegetable oil. The crop is known to suffer from several diseases. Among them, rust caused by Puccinia arachidis Speg. assumes greater significance as this disease is found to occur regularly in Gujarat during kharif season. The bio molecules such as total soluble sugars, protein and total phenol content were increased due to rust infection in the resistant entries PI-476177 and PI-476168. The rate of accumulation of biomolecules such as total soluble sugars, protein and total phenol contents observed higher in susceptible entries PI-476165 and J-11, as compared to resistant entries. The amino acids content were decreased in both resistant and susceptible entries due to rust infection. The micronutrient content copper and zinc was found higher in resistant entries while iron and manganese content was found higher in the susceptible entries. The micronutrient content was increased in the fungicide treated groundnut plants compared to the untreated plants.

\section{Introduction}

Groundnut (Arachis hypogaea L.) is one of the most important oilseed crop of the world and one out of the nine annual oilseed crops of India. India ranks first in area (5 million hectares) and second in production (4.625 million tonnes) in the world, though the productivity level is less than half of the major groundnut growing countries and around one-third of the best of world levels (Singhal, 2003). In India, it is also known as a poor man's almond. Rust (Puccinia arachidis Speg.) is one of the important biotic stress factors that greatly affects groundnut yield quantity and quality.
Management of rust disease with fungicides is expensive and the application of chemicals increases the risk to global environmental safety (Engin et al., 2016). Among the major fungal diseases, rust caused by Puccinia arachidis Speg. was observed for the first time in Gujarat at pathological farm, Junagadh in 1973 by Vaishnav (Vaishnav and Kapadia, 1982). Rust was severe particularly in the southern states of India (Subrahmanyam et al., 1979). Survey conducted by the National Research Centre for Groundnut (NRCG), Junagadh revealed that the rust with moderate to 
heavy severity was distributed in all groundnut-growing districts of Saurashtra region of Gujarat (Ghewande and Mishra, 1983). Rust was present in almost all rabi/summer groundnut cultivation areas in India (Subrahmanyam and Mc Donald, 1986). Looking to the destructive nature of the disease and limited information on many aspects of pathogen and control of this disease, present investigation was undertaken to study the symptoms produced due to infection of the fungus on groundnut. Attempts also made to assess the losses and to find out the source of resistance if any through varietal screening and biochemical changes during disease development. The newer fungicides were also screened under field condition to manage the disease.

\section{Materials and Methods}

\section{Collection of samples}

The naturally infected leaves of groundnut (Arachis hypogaea L.) PI-476168 (R), PI476177 (R), PI-476165 (S) and J-11 (S) showing typical late leaf spot symptoms were collected from Main Oilseeds Research Station, Collage of Agriculture, Junagadh Agricultural University (JAU), Junagadh. The infected leaves were thoroughly washed with running tap water and then, immediately examined under a compound microscope for preliminary identification of the pathogen.

\section{Biochemical changes due to rust}

For studying biochemical changes in rust infected leaves of groundnut, leaves were collected at 30,60 and 90 days after sowing. Care was taken to select only such leaves, which were identical in age, size and shape. Analysis for the estimation of protein (Lowry et al., 1951), phenol (Bray and Thorpe, 1954) total soluble sugar (Dubois et $a l ., 1956)$, and free amino acids content (Lee and Takahashi, 1966) carried out using methods suggested by respective scientists. The micronutrients were determined on Atomic absorption spectrophotometer method described by Lindsay and Norvell (1978).

\section{Results and Discussion}

\section{Biochemical changes in response to infection of Puccinia arachidis in groundnut}

The 22 entries were sown at the Research farm of Main Oilseeds Research Station, JAU, Junagadh. Out of 22 entries, four entries were selected (two each of resistant and susceptible) for the estimation of biochemical attributes such as protein, total soluble sugars, total phenols and free amino acids on the basis of their disease reaction.

The results of the various biomolecules such as total soluble sugars, protein, total Phenol and free amino acids contents are presented in Table 1. In thie research four groundnut entires were selected and analyzed for the biochemical composition of various stages of disease development.

\section{Total soluble sugar}

It is evident from the Table 1 that total sugars content in groundnut leaves varied from 0.07 to $0.21 \mathrm{mg} / \mathrm{g}$ fresh weights. In the initial stage (30 DAS), the total sugar content was varied from 0.073 to 0.157 $\mathrm{mg} / \mathrm{g}$ fresh weight and increased in all entries at 60 DAS. The sugar content was decreased at 90 DAS in entries PI-476165 and J-11. Data clearly showed that with increasing disease resistance the total soluble sugars also increased in diseased leaves. Reddy and Gopal (1982) observed the change in organic acid and sugar in 
infected leaves and reported that sugars like glucose, sucrose and fructose increased and organic acid decreased with disease development. Li Dun et al., (1995) reported that susceptible cultivar had higher soluble sugar than resistant one. Ekbote and Mayee (1983) found that total sugars were increased in inoculated plants as compared to healthy ones, while gradual decreased in ascorbic acid content was observed in rust inoculated plants over healthy ones.

\section{Protein}

The protein content was increased as disease increased in both susceptible and resistant entries (Table 1). In resistant entries i.e PI476177 the protein content increased from $12.29 \mathrm{mg} / \mathrm{g}$ while in the susceptible entries PI-476165 it increased from $12.08 \mathrm{mg} / \mathrm{g}$. The mean protein content was also increased from pre-infection to post infection stage. The increase in protein content from pre infection to post infection stages was higher in resistant entries J-11 as compared to susceptible entries. Siddaramaiah et al., (1979) reported the remarkable increase in protein content and water-soluble sugars in severely rust infected leaves of groundnut with compared to healthy leaves.

\section{Total phenols}

The phenols in four entries varied from 4.72 to $8.18 \mathrm{mg} / \mathrm{g}$ fresh weight (Table 1). In the initial stage, phenol content varied from 5.86 to $7.66 \mathrm{mg} / \mathrm{g}$ fresh weight in both resistant and susceptible entries. Total phenol content at 90 DAS was higher in both resistant entries (PI-476168 and PI-476177) as 8.03 and $8.25 \mathrm{mg} / \mathrm{g}$ fresh weight respectively, while in susceptible entries (PI-476165 and $\mathrm{J}-11$ ) the phenol content was 7.14 and 7.21 $\mathrm{mg} / \mathrm{g}$ fresh weight, respectively. So increase in phenol content was more in resistant entries as compared to susceptible entries.
Reddy $(1983,1984)$ noted that contents of almost all phenolics were higher in infected leaves initially and continued to rise with progress of infection. There were found to increase synthesis of total phenols particularly in ortho-dihydroxy phenols in plant tissues of resistant genotypes (ICG 7013 and ICG 7885) after disease initiation (Reddy and Ravindranath, 1988).

The total phenols increased in response to infection by $P$. arachidis in resistant cultivars (Kumar and Balasubramanian, 2000; Meena et al., 2000 and Sudhagar et al., 2000).

\section{Free Amino acids}

It is seen from the Table 1 that higher content of free amino acids were observed in the early stages of infection and then disappeared. The free amino acids content were increased from pre infection to infection stage and then it was decreased at post infection stage. Amino acids were decreased from 7.85 to $2.66 \mathrm{mg} / \mathrm{g}$ in both resistant and susceptible entries. In the initial stage, the free amino acids content was higher in both resistant and susceptible entries above $5 \mathrm{mg} / \mathrm{g}$ and then it decreased post infection stage. The mean free amino acids content of resistant entries was higher than susceptible entries. Several amino acids like leucine, isoleucine, histidine and alanine were sensitive to infection because they decreased to low levels (Li-Dun et al., 1995).

\section{Micronutrientional changes in response to infection of Phaeoisariopsis personata in groundnut}

The copper, iron, zinc and manganese contents in leaves of four groundnut entries at different stages of disease development are presented in Table 2. 
Table.1 Changes in total soluble sugars, True Protein, Total Phenol and Free Amino acid contents (mg.g-1.fr.wt) in resistant and susceptible groundnut entries during disease development stages

\begin{tabular}{|c|c|c|c|c|c|c|c|c|c|c|c|c|c|c|c|c|}
\hline & \multicolumn{4}{|c|}{ total soluble sugars } & \multicolumn{4}{|c|}{ True Protein } & \multicolumn{4}{|c|}{ Total Phenol } & \multicolumn{4}{|c|}{ Free Amino acid } \\
\hline & \multicolumn{3}{|c|}{ Stages of infection } & \multirow[b]{2}{*}{ Mean } & \multicolumn{3}{|c|}{$\begin{array}{l}\text { Stages of } \\
\text { infection }\end{array}$} & \multirow[b]{2}{*}{ Mean } & \multicolumn{3}{|c|}{ Stages of infection } & \multirow[b]{2}{*}{ Mean } & \multicolumn{3}{|c|}{ Stages of infection } & \multirow[b]{2}{*}{ Mean } \\
\hline & $\mathbf{S}_{1}$ & $\mathbf{S}_{\mathbf{2}}$ & $\mathbf{S}_{\mathbf{3}}$ & & $\mathbf{S}_{1}$ & $\mathbf{S}_{2}$ & $\mathbf{S}_{3}$ & & $\mathbf{S}_{1}$ & $\mathbf{S}_{\mathbf{2}}$ & $\mathbf{S}_{3}$ & & $\mathbf{S}_{1}$ & $\mathbf{S}_{2}$ & $\mathbf{S}_{\mathbf{3}}$ & \\
\hline $\begin{array}{l}\text { PI-476168 } \\
\text { (R) }\end{array}$ & 0.157 & 0.182 & 0.194 & 0.178 & 6.16 & 8.73 & 14.11 & 9.67 & 5.72 & 6.16 & 8.03 & 6.64 & 7.85 & 3.37 & 3.86 & 5.03 \\
\hline $\begin{array}{l}\text { PI-476177 } \\
\text { (R) }\end{array}$ & 0.103 & 0.185 & 0.213 & 0.167 & 6.09 & 8.24 & 12.29 & 8.87 & 5.61 & 6.28 & 8.25 & 6.71 & 5.92 & 2.69 & 3.53 & 4.05 \\
\hline $\begin{array}{l}\text { PI-476165 } \\
\text { (S) }\end{array}$ & 0.103 & 0.190 & 0.159 & 0.151 & 5.30 & 7.45 & 12.08 & 8.28 & 6.10 & 6.76 & 7.14 & 6.67 & 7.59 & 3.10 & 2.66 & 4.45 \\
\hline $\mathrm{J}-11(\mathrm{~S})$ & 0.073 & 0.207 & 0.142 & 0.141 & 6.79 & 8.90 & 13.34 & 9.68 & 5.99 & 6.52 & 7.21 & 6.57 & 5.18 & 3.17 & 3.06 & 3.81 \\
\hline Mean & 0.109 & 0.191 & 0.177 & & 6.08 & 8.33 & 12.96 & & 5.86 & 6.43 & 7.66 & & 6.64 & 3.08 & 3.28 & \\
\hline & $\mathrm{E}$ & $\mathrm{S}$ & $\mathrm{E} \times \mathrm{S}$ & & $\mathrm{E}$ & $\mathrm{S}$ & $E \times S$ & & $\mathrm{E}$ & $\mathrm{S}$ & $E \times S$ & & $\mathrm{E}$ & $\mathrm{S}$ & $E \times S$ & \\
\hline S. Em. \pm & 0.0023 & 0.0027 & 0.0046 & & 0.13 & 0.15 & 0.26 & & 0.10 & 0.11 & 0.20 & & 0.08 & 0.09 & 0.15 & \\
\hline C. D. at $5 \%$ & 0.0068 & 0.0078 & 0.0135 & & 0.38 & 0.44 & 0.77 & & 0.28 & 0.33 & 0.57 & & 0.22 & 0.26 & 0.45 & \\
\hline
\end{tabular}

$\mathrm{S}_{1}=$ Pre infection, $\mathrm{S}_{2}=$ Infection, $\mathrm{S}_{3}=$ Post infection, $\mathrm{R}=$ Resistant, $\mathrm{S}=$ Susceptible, $\mathrm{E}=$ Entries 
Table.2 Changes in (ppm) in leaves of groundnut entries at different stages of infection

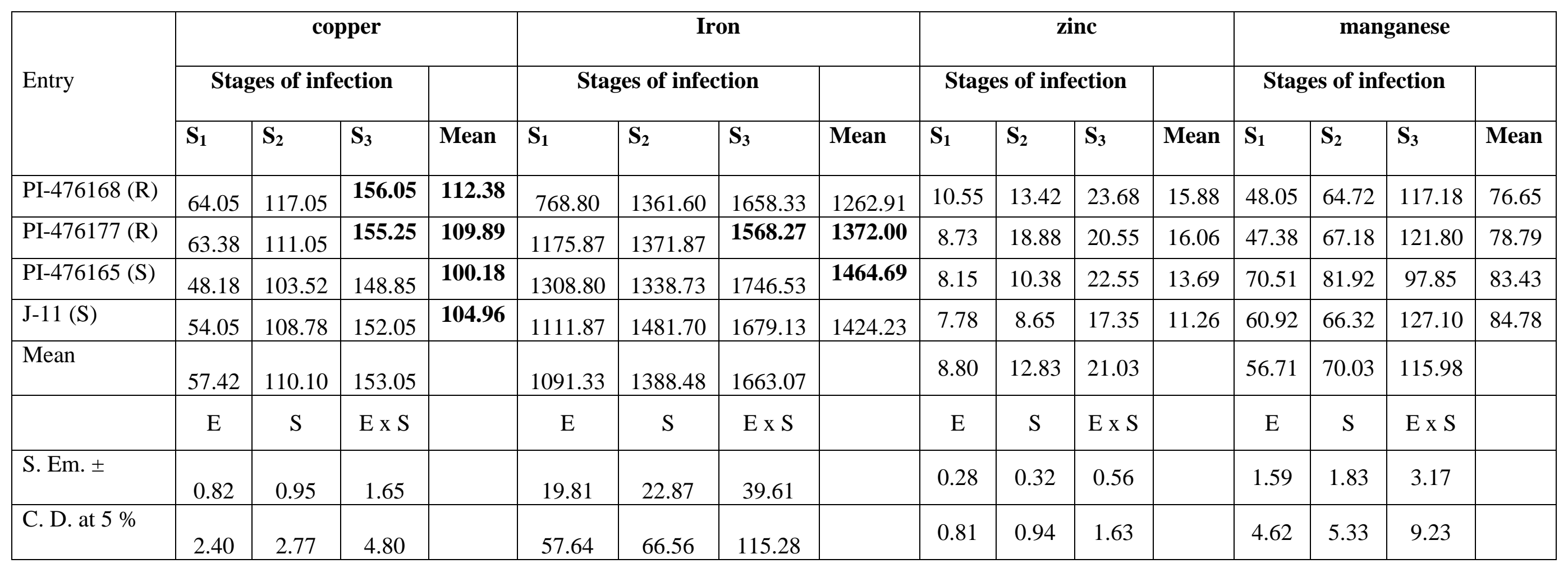


Table.3 Changes in micronutrient content ( $\mathrm{ppm}$ ) in groundnut pods in different entries at harvest stage

\begin{tabular}{|l|c|c|c|c|}
\hline \multicolumn{1}{|c|}{ Entry } & Copper & Iron & Zinc & Manganese \\
\hline PI-476168 (R) & 228.98 & 1173.03 & 28.42 & 36.14 \\
\hline PI-476177 (R) & 218.98 & 1066.87 & 26.35 & 31.92 \\
\hline PI-476165 (S) & 203.65 & 1551.80 & 14.68 & 46.72 \\
\hline J-11 (S) & 193.98 & 1315.03 & 12.60 & 41.45 \\
\hline S. Em. \pm & 4.94 & 42.05 & 0.66 & 1.54 \\
\hline C. D. at 5 \% & 16.05 & 136.74 & 2.15 & 5.00 \\
\hline
\end{tabular}

\section{Copper}

It is revealed from the Table 2 that the copper content was increased as infection progress in both susceptible and resistant entries. The copper content was increased from 57.42 to $153.05 \mathrm{ppm}$. All the entries were significantly differed from each other in pre infection stage. The mean copper content was high in both the resistant entries (PI-476168 and PI-476177) where as it was low in susceptible entries PI-476165 and J11. The mean copper content at different infection stages was also increased with infection.

\section{Iron}

The mean iron content was increased from 1091.33 to $1663.07 \mathrm{ppm}$ with the increase of infection subsequently. The mean iron content of susceptible entries PI-476165 (1464.69 ppm) and J-11 (1424.23 ppm) was significantly higher as compared to resistant entries PI-476168 (1262.91) and PI-476177 (1372.00).

\section{Zinc}

The zinc content was increased subsequently with progress of infection in both susceptible and resistant entries. The significant difference in zinc content was noted at pre infection stage in all entries. The mean zinc content increased with the progress of infection and it was increased from 8.80 to $21.03 \mathrm{ppm}$. The mean zinc content was higher in resistant entries PI476177 (16.06 ppm) closely followed by PI476177. However, they were statistically at par. The zinc content was significantly lower in susceptible cultivar as compared to resistant.

\section{Manganese}

From the table 2 it is revealed that the manganese content was increased with the progress of infection in both susceptible and resistant entries. At post infection stage, manganese content was increased greatly as compared to pre infection stage. The manganese content in resistant entries PI476168 (76.65 ppm) and PI-476177 (78.79 ppm) was at par and significantly lower than susceptible entries (PI-476165 and J-11). However, there was no significant difference of manganese content in susceptible entries.

Jeun and Hwang (1991) reported that the contents of macronutrients such as $\mathrm{N}, \mathrm{P}, \mathrm{K}$, $\mathrm{Ca}$ and $\mathrm{Mg}$ decreased greatly in both 
resistant and susceptible cultivars against Phytophthora capsici during growth stage whereas silica and micronutrient contents did not change significantly with growth stage. Sindhan and Parashar (1996) concluded that $\mathrm{N}, \mathrm{Mn}$ and Fe contents were low and $\mathrm{P}, \mathrm{K}, \mathrm{Zn}$, and $\mathrm{Cu}$ were higher in leaf spot resistant cultivars of groundnut.

The content of different micronutrients at harvesting stage in pods of susceptible and resistant entries was differed in all entries. The copper content was varied from 228.98 to $193.98 \mathrm{ppm}$. The iron content varied from 1066.87 to $1551.80 \mathrm{ppm}$. The zinc content was varied from 12.60 to $28.42 \mathrm{ppm}$. The zinc content was significantly higher and statistically at par in resistant entries PI476168 (28.42 ppm) and PI-476177 (26.35 ppm). Whereas it was lower in susceptible entries. The manganese content was significantly lower and at par in resistant entries PI-476168 and PI-476177, however it was higher in susceptible entries.

Overall it can be concluded that, the total soluble sugars, protein and phenols content were increased in resistant entries PI-476168 and PI-476177 where as the amino acid content was decreased with rust infection in field condition. The micronutrient copper and zinc content were higher in both resistant entries then susceptible entries PI476165 and $\mathrm{J}-11$, whereas iron content was lower in resistant entries and higher in susceptible entries.

\section{References}

Bray, H.G. and Thorpe, W.V. 1954. Analysis of phenolic compounds of interest in metabolism. Meth. Biochem. Ann., 1: 27-52.

Das, P.C. 1997. "Oil seed Crops of India". Kalyani Publishers, Ludhiana, India, pp. 80-83.
Dobois, M.J., Gillies, R.A., Hemilton, J.K., Rebers, P.A. and Smith, F. 1956. Colourimetric method for determination of sugars and related substances. Anal. Chem., 23: 350-356.

Ekbote, A.U. and Mayee, C.D. 1983. Biochemical changes in rust (Puccinia arachidis) resistant and susceptible varieties of groundnut after inoculation. Indian phytopath., 36: 194.

Engin, Yo., Hari, D.U. and Bulent, U. 2016. Identification of rust resistance in groundnut using a validated SSR marker. Euphytica, 210(3): 405-411.

Ghewande, M.P. and Mishra, D.P. 1983. Groundnut Rust - A challenge to meet. Seeds and Farms, 9: 12-15.

Ghuge, S.S., Mayee, C.D. and Godbole, G.M. 1981. Assessment of losses in peanut due to rust and tikka leaf spots. Indian Phytopath., 34: 179-182.

Jeun, Y.C. and Hwang, B.K. 1991. Carbohydrate, amino acid, phenolic and mineral nutrient contents of pepper plants in relation to age-related resistance to Phytophthora capsici. J. Phytopath., 131(1): 40-52.

Kolte, S.J. 1987. Diseases of Annual Edible Oilseed Crops. Vol. 1. Peanut Diseases. CRC Press, Inc. Boca Raton, Florida, pp. 1-7.

Lee, Y.P. and Takahashi, T. 1966. An improved colourimetric determination of amino acids with the use of ninhydrin. Anal. Bio. Chem., 14: 71.

Li, Dun, Wang, ZhenZhong, Lin, Kong Xun, Li, D., Wang, Z.Z. and Lin, K.X. 1995. Dynamics of several biochemical components in peanut plants after rust infection and their relationships to disease resistance. $J$. South China Agric. Uni., 16(1): 68-75.

Lindsay, W.L. and Norwell, W.A. 1978. Development of a DTPA soil test for zinc, iron, manganese and copper. Soil 
Sci. Soc. Ann. J., 42: 421-248.

Lowry, O.W., Rosebraugh, N.J., Farr, A.C. and Randall, R.J. 1951. Protein measurements with Folin phenol reagent. J. Biol. Chem., 193: 225-257.

McDonald, D., Subrahmanyam, P., Gibbons, R.W. and Smith, D.H. 1985. Early and late leaf spots of groundnut. ICRISAT- Information Bulletin.No.21. International Crops Research Institute for Semi-Arid Tropics, Patancheru, Andhra Pradesh., 502324, India. pp.19.

Reddy, M. N. (1983). Changes in phenolic acids in groundnut leaves infected with Puccinia arachidis Speg. Acta Phytopathologica Academiae Scientiarum Hungaricae 18 (1-3): 4547.

Reddy, M.K. and Ravindranath, V. 1988. Polyphenols in relation to rust resistance in groundnut genotypes. Nat. Acad. Sci. Lett. India, 11(2): 3941.

Reddy, M.N. 1984. Changes in phenolic acids in groundnut leaves infected with rust. Phytopathologische Zeitschrift, 110(1): 78-81.

Reddy, M.N. and Gopal, G.R. 1982. Changes in organic acids and sugars in the rust infected groundnut leaves. Indian Phytopath., 35(4): 728-730.
Siddaramaiah, A.L., Vasuki, N., Baroma Goudar, T.D., Lingaraju, S. and Hedge, R.K. 1979. Biochemical changes in rust infected leaves of groundnut. Indian Phytopath., 32: 640-642.

Sindhan, G.S. and Parashar, R.D. 1996. Biochemical changes in groundnut leaves due to infection by early and late leaf spot pathogen. Indian $J$. Mycol. and Pl. Pathol., 26(2): 210212.

Singhal Vikas. 2003. Indian Agriculture. Indian Economic Data Research Centre, New Delhi. pp. 398-399.

Subrahmanyam, P. and McDonald, D. 1986. Disease of rabi groundnut in India. "Work-shop-cum-seminar on high yielding technology for Rabi/summer Oilseeds, Directorate of Oilseeds Research, Rajendranagar, Hyderabad30, November 25, 1986.

Subrahmanyam, P., Reddy, D.V.R., Gibbons, R.W., Rao, V.R. and Garren, K.H. 1979. Current distribution of groundnut rust in India. PANS, 25(1): 25.

Vaishnav, M.U. and Kapadia, M.N. 1982. Occurrence of a mycophagous midge, Mycodiplosis sp. on groundnut rust in Gujarat. Pesticides, 16(7): 21.

\section{How to cite this article:}

Rojasara, Y.M., Rutika Shah, J.J. Dhuve and Dhruj, I.U. 2016. Changes in Biomolecules of Groundnut Leaves infected with Rust (Puccinia arachidis speg). Int.J.Curr.Microbiol.App.Sci. 5(10): 362-369. doi: http://dx.doi.org/10.20546/ijcmas.2016.510.041 